\title{
Economics and yield performance of some short duration fruit and medicinal crops under agrisilvicultural system in rainfed uplands of Odisha
}

\author{
M. R. Nayak ${ }^{1 *}$, L. K. Behera ${ }^{1}$, P. J. Mishra ${ }^{2}$ and N. Bhola ${ }^{3}$ \\ ${ }^{1}$ Department of Silviculture and Agroforestry, ASPEE College of Horticulture and Forestry, Navsari Agricultural \\ University, Navsari, INDIA \\ ${ }^{2}$ AICRP on Agroforestry, Orissa University of Agriculture and Technology, Bhubaneswar, INDIA \\ ${ }^{3}$ Department of Silviculture and Agroforestry, College of Forestry, Orissa University of Agriculture and \\ Technology, Bhubaneswar, INDIA \\ *Corresponding author. E-mail: manas.forestry@ gmail.com
}

Received: April 23, 2014; Revised received: May 20, 2014; Accepted: June 5, 2014

\begin{abstract}
A field experiment was conducted during 2011-12 in an agrisilvicultural system consisting of two silvicultural species viz. Acacia mangium (mangium) and Gmelina arborea (gamhar) planted in 2000 at a spacing of $8 \mathrm{~m} \times 2 \mathrm{~m}$ and four agricultural crops viz. Ananas comosus (pineapple), Aloe vera (aloevera), Andrographis paniculata (kalmegh) and Curcuma amada (mangoginger) were raised in the $1^{\text {st }}$ week of July, 2011. The maximum volume increment were achieved by mangium with pineapple $\left(16.53 \mathrm{~m}^{3} / \mathrm{ha}\right)$. Pineapple also registered the maximum fruit yield of $9981 \mathrm{Kgha}^{-1}$ under mangium and minimum under gamhar $\left(9106 \mathrm{Kgha}^{-1}\right)$. The fresh leave yield of aloevera $\left(8635 \mathrm{Kg} \mathrm{ha}^{-1}\right)$ was maximum under mangium which is statistically at par with gamhar. However, kalmegh recorded maximum dry plant yield of $1239 \mathrm{Kgha}^{-1}$ under open condition followed by $1072 \mathrm{Kgha}^{-1}$ under gamhar and $823 \mathrm{Kgha}^{-1}$ under mangium. Similarly, mangoginger exhibited maximum rhizome yield of $3300 \mathrm{Kgha}^{-1}$ under open condition followed by $1979 \mathrm{Kgha}^{-1}$ under gamhar and $1597 \mathrm{Kgha}^{-1}$ under mangium. The trend of crop yield under both the trees and open condition was: Pineapple >Aloevera>Mangoginger>Kalmegh. A. mangium with pineapple based agrisilvicultural system recorded the highest gross return, net return and BCR as compared to other agrisilvicultural systems and sole crops.
\end{abstract}

Keywords: Agrisilvicultural system, BCR, Economics, Gamhar, Mangium, Yield

\section{INTRODUCTION}

Agroforestry is a land use system that involves deliberate retention, introduction, or mixture of trees or other woody perennials in crop/animal production field to benefit from the resultant ecological and economical interactions (Chaturvedi and Krishnan, 2009). Again it plays the major role to overcome the problems of global climate change, reduces the pressure on natural forests, fulfils the requirement of various tangible and intangible returns from trees, etc. in the present world demanding context. An efficient agroforestry system would aim at systematically developing integrated land use systems and practices where the positive interaction between trees and crops are encouraged and maximized. Agroforestry offers an economical and ecologically viable option for large scale diversification in agriculture on one hand and environmental amelioration on the other. Hence to save forests and meet the growing demands of wood, there is need for large scale plantations of fast growing tree species outside forests to make country self reliant in its timber requirements. On-farm timber tree plantations can also benefit from the global environmental facilities like carbon trading (Pandey,
2007 and Dogra, 2007). Therefore, there is a great need to identify the suitable agricultural and horticultural crops, which can grow well along with tree species with limited solar energy available underneath the trees. The choice of intercrop also depends on characteristics of particular tree species e.g. root system, canopy, allelopathic effect of litter andtechnical factors viz. agro-climatic and edaphic conditions (Batish et al., 2007). In the present investigation, one fruit crop like Ananas comosus (pineapple) and three medicinal crops like Aloe vera (aloevera), Andrographis paniculate (kalmegh) and Curcuma amada (mangoginger) were intercropped with the two established tree species of Acacia mangium (mangium) and Gmelina arborea (gamhar). These crops are selected on the basis of their adaptation, growing habit, production and requirement. Similarlyexotic tree species A. mangium (mangium) is gaining popularity in Odisha because of its fast growing nature, transit free logging, transport and huge demand from pulp and paper industries. Again indigenous fast growing tree species $G$. arborea (gamhar) wood is even-grained, soft, light and strong for which it is demanded for panelling, carriages, furniture, boxes and carpentry of all kinds. With these 
views, the present investigation was carried out to find the effect of mangium and gamhar trees on growth, yield and economics with pineapple, aloevera, kalmegh and mangoginger intercrops over mono-cropping.

\section{MATERIALS AND METHODS}

The present experiment on economics and yield performance of some short duration fruit and medicinal crops under agrisilvicultural system in rainfed uplands of Odisha was carried out at the experimental farm of All India Coordinated Research Project (AICRP) on Agroforestry, Orissa University of Agriculture and Technology (OUAT), Bhubaneswar centre during July, 2011- June, 2012. The experiment consisted of two silvicultural tree species such as $A$. mangium (mangium) and G. arborea (gamhar) at a spacing of $8 \mathrm{~m} \times 2 \mathrm{~m}$ and four agricultural crops such as A. comosus (pineapple), A. vera (aloevera), A. paniculata (kalmegh) and $C$. amada (mangoginger) were planted at spacing of $60 \mathrm{~cm} \times 60 \mathrm{~cm}, 45 \mathrm{~cm} \times 60$ $\mathrm{cm}, 30 \mathrm{~cm}$ x $30 \mathrm{~cm}$ and $25 \mathrm{~cm}$ x $30 \mathrm{~cm}$ respectively. The experiment was laid out in Randomised Block Design (RBD) with three replications and total of 36 plots including 12 plots for sole crops. Land preparation was started with one summer ploughing in the month of May, 2011 followed by two ploughings and laddering. The experimental plot was led out into small plots of size $16 \mathrm{~m}$ x $6 \mathrm{~m}$ for different treatments. The crops such as pine apple, aloevera, kalmegh and mangoginger were raised in the $1^{\text {st }}$ week of July, 2011. Pineapple and aloevera were raised from suckers where as kalmegh was raised from seedlings and mangoginger by rhizomes. At the time of final land preparation well decomposed Farm Yard Manure (FYM) 10 t/ha and uniform common dose of 25-50-50 $\mathrm{kg}$ of $\mathrm{N}-\mathrm{P}_{2} \mathrm{O}_{5}-\mathrm{K}_{2} \mathrm{O}$ per hectare in the form of urea, di-ammonium phosphate (DAP) and murate of potash (MOP) were applied respectively. Half of the nitrogen along with full phosphorus and potash were applied as basal dose and rest of nitrogen as top dressing 30 days after planting. Hoeing and weeding were carried out at three weeks interval for initial three months for every crop. The light intensity was observed during the months of September, October and November, 2011 under different treatments. The pineapple fruits were harvested in the month of April and May, 2012 at weekly interval whereas leaves of aloevera were harvested in the month of June, 2012 in one lot selecting only matured leaves. Similarly the entire plant of kalmegh was harvested in the month of November, 2011 by uprooting and the rhizomes of mangoginger were harvested in the first fortnight of December 2011. The growth and yield parameters of trees and intercropswere recorded and analysed as per the procedure described for RBD (Panse and Sukhatme, 1978). Standard error of means i.e. $\mathrm{SE}_{\mathrm{m}}( \pm)$ and Critical Difference (CD) were calculated at 5\% level of significance and compared the treatments means, wherever ' $F$ ' test was found significant. Also the economics of agrisilvicultural systems were calculated and compare to respective sole crops.

\section{RESULTS AND DISCUSSION}

The growth of two tree species i.e. mangium and gamhar under agrisilvicultural system varied significantly among different treatments (Table 1). At the end of cropping season, the Diameter at Breast Height (DBH), height and annual stem volume of 11 year old mangium and gamhar with four intercrops differed appreciably and resulting significant variation in the annual increment of volume.The growth parameters of trees like $\mathrm{DBH}$, height and volume were remarkably higher in mangium as compared to gamhar. This may be attributed to the genetic ability of mangium having faster growth rate than gamhar and the dry land situation of the experimental site not suitable for good growth of gamhar. The data indicated that the growth and yield of both the tree species were not influenced by any particular intercrop tried. This may be due to the fact that the intercrops were grown for short period and both the tree species had already grown up of 11 years age. Similar findings have been reported in rhodes grass intercropped with

Table 1. Growth performance of Mangium and Gamhar (11year old) in the agrisilvicultural system.

\begin{tabular}{|c|c|c|c|c|c|c|c|}
\hline \multirow{2}{*}{ Treatment } & \multicolumn{3}{|c|}{$\begin{array}{c}\text { At the beginning of cropping } \\
\text { season }\end{array}$} & \multicolumn{3}{|c|}{$\begin{array}{l}\text { At the end of cropping } \\
\text { season }\end{array}$} & \multirow{2}{*}{$\begin{array}{c}\text { Annual } \\
\text { increment } \\
\text { in volume } \\
\left(\mathbf{m}^{3} / \mathbf{h a}\right)\end{array}$} \\
\hline & $\begin{array}{c}\mathrm{DBH} \\
(\mathrm{cm})\end{array}$ & $\begin{array}{l}\text { Height } \\
\text { (m) }\end{array}$ & $\begin{array}{c}\text { Volume of } \\
\text { stem }\left(\mathrm{m}^{3} \mathrm{ha}^{-1}\right)\end{array}$ & $\begin{array}{c}\text { DBH } \\
(\mathrm{cm})\end{array}$ & $\begin{array}{l}\text { Height } \\
\text { (m) }\end{array}$ & $\begin{array}{c}\text { Volume } \\
\text { of stem } \\
\left(\mathbf{m}^{3} \mathbf{h a}^{-1}\right)\end{array}$ & \\
\hline $\mathrm{T}_{1}-$ Mangium + Pineapple & 24.01 & 18.23 & 164.74 & 24.35 & 19.12 & 181.27 & 16.53 \\
\hline $\mathrm{T}_{2}-$ Mangium + Aloevera & 23.61 & 18.17 & 163.87 & 24.18 & 19.01 & 179.37 & 15.49 \\
\hline $\mathrm{T}_{3}-$ Mangium + Kalmegh & 23.89 & 18.25 & 165.32 & 24.31 & 19.13 & 181.43 & 16.18 \\
\hline $\mathrm{T}_{4}-$ Mangium + Mangoginger & 23.86 & 18.15 & 163.82 & 24.28 & 18.98 & 178.96 & 15.13 \\
\hline $\mathrm{T}_{5}-$ Gamhar + Pineapple & 7.71 & 6.79 & 7.84 & 8.05 & 7.71 & 11.45 & 3.61 \\
\hline $\mathrm{T}_{6}-$ Gamhar + Aloevera & 7.78 & 6.81 & 8.53 & 8.09 & 7.72 & 12.13 & 3.54 \\
\hline $\mathrm{T}_{7}-$ Gamhar + Kalmegh & 7.82 & 6.87 & 8.19 & 8.10 & 7.75 & 11.85 & 3.65 \\
\hline $\mathrm{T}_{8}-$ Gamhar + Mangoginger & 7.89 & 6.93 & 8.81 & 8.12 & 7.78 & 12.38 & 3.56 \\
\hline $\operatorname{SEm}( \pm)$ & 0.009 & 0.005 & 0.150 & 0.011 & 0.073 & 0.155 & 0.13 \\
\hline $\mathrm{CD}_{(0.05)}$ & 0.028 & 0.017 & 0.456 & 0.036 & 0.222 & 0.470 & 0.44 \\
\hline
\end{tabular}


Table 2. Growth and yield performance of pineapple, aloevera, kalmegh and mangoginger under agrisilvicultural system.

\begin{tabular}{lccc}
\hline Treatment & Plant height $(\mathbf{c m})$ & Leaves $($ Branches)/ plant* & ${\text { Yield }\left(\text { Kgha }^{-\mathbf{1}}\right)}$ \\
\hline $\mathrm{T}_{1}$ - Mangium + Pineapple & 82.7 & 38.1 & 9981 \\
$\mathrm{~T}_{2}$ - Mangium + Aloevera & 48.6 & 14.1 & 8635 \\
$\mathrm{~T}_{3}$ - Mangium + Kalmegh & 32.8 & 14.2 & 823 \\
$\mathrm{~T}_{4}$ - Mangium + Mangoginger & 69.4 & 6.9 & 1597 \\
$\mathrm{~T}_{5}$ - Gamhar + Pineapple & 80.4 & 42.5 & 9106 \\
$\mathrm{~T}_{6}$ - Gamhar + Aloevera & 46.1 & 12.7 & 7828 \\
$\mathrm{~T}_{7}$ - Gamhar + Kalmegh & 39.0 & 17.4 & 1072 \\
$\mathrm{~T}_{8}$ - Gamhar + Mangoginger & 79.0 & 8.9 & 1979 \\
$\mathrm{~T}_{9}$ - Pineapple & 76.6 & 43.6 & 7218 \\
$\mathrm{~T}_{10}$-Aloevera & 33.0 & 12.3 & 7095 \\
$\mathrm{~T}_{11}$-Kalmegh & 42.5 & 18.2 & 1239 \\
$\mathrm{~T}_{12}$-Mangoginger & 81.7 & 8.8 & 3300 \\
$\mathrm{SEm}_{( \pm)}$ & 2.79 & 1.56 & 366 \\
$\mathrm{CD}_{(0.05)}$ & 8.19 & 4.63 & 1071 \\
\hline
\end{tabular}

*Leaves/ plant in pineapple, aloevera and mangoginger; Branches/ plant in kalmegh.

three tree species A. nilotica, Dalbergia sissoo and Casuarina equisetifolia (Batra and Kumar, 1994), bean (Phaseolus vulgaris) raised in Eucalyptus grandis (Couto and Gomes, 1995) and castor (Ricinus communis) and greengram (Vigna radiata) grown under three agroforestry tree species like Emblica officinalis, Tamarindus indica and A. senegal (Korwar et al., 2006). Likewise the growth and yield of four intercrop were studied and found that the plant height and number of leaves or branches/ plant of different intercrops varied significantly from one another (Table 2). The height of plant varied from $32.8 \mathrm{~cm}$ to $82.7 \mathrm{~cm}$ pineapple under mangium recorded the maximum height $(82.7 \mathrm{~cm})$ while kalmegh under mangium recorded the minimum height $(32.8 \mathrm{~cm})$. The variation in height of different intercrops may be attributed to the genetically character of intercrops and availability of light intensity under trees (Table 3) Light availability is the most important limiting factor for the performance of under storey annual crops particularly where upper storey perennial from a dense over storey canopy (Acciaresi et al., 1994). Furthermore the number of leaves/ plant in pineapple, aloevera, mangoginger and number of branches/ plant in kalmegh differed significantly under different treatments. The number of leaves /plant varied from 6.9 to 43.6. Pineapple under open condition registered the maximum number of leaves (43.6) while mangoginger under mangium recorded the minimum of (6.9). In most of the crops the number of leaves (branches)/ plant was relatively higher in open condition than under tree canopy because of availability of more light. The results are in line with the findings of rice and mungbean intercropped with A. mangium, A. auriculiformis and Gliricidia sepium (Miah et al. (1997) and wheat varieties were raised in agrisilvicultural system (Puri et al. (2001). The data on yield performance of different intercrops revealed that yield varied significantly in different treatments. Pineapple under mangium registered the maximum fruit yield of 9981 $\mathrm{Kg}$ / ha while kalmegh under mangium registered the minimum dry plant yield of $823 \mathrm{Kg} / \mathrm{ha}$. The yield performance of pineapple under mangium was at par with the yield under gamhar $(9106 \mathrm{Kg} / \mathrm{ha})$, however, the yield under agrisilvicultural systems were significantly higher over the open condition $(7218 \mathrm{Kg} /$ ha). The fresh leave yield of aloevera $(8635 \mathrm{Kg} / \mathrm{ha})$ was more under mangium than under gamhar (7828 $\mathrm{Kg} / \mathrm{ha}$ ) but the values were statistically at par with each other. Yield performance of aloevera under agrisilvicultural system was significantly higher over the open condition (7095 Kg/ha). Pineapple and aloevera yield more under trees than open condition. This may be attributed to their shade loving nature under such dry land situation. The results are in line with the findings for ginger, turmeric and colocasia intercropped with Pinus khasya (Dhyani and Chauhan, 1989), ginger raised under coconut (Jayachandran et al., 1991) and ginger and turmeric grown under poplar (Jasural et al., 1993). Again the yield of kalmegh and mangoginger were more in open condition than under agrisilvicultural system. Kalmegh recorded maximum dry plant yield of $1239 \mathrm{Kg} / \mathrm{ha}$ under open condition followed by $1072 \mathrm{Kg} / \mathrm{ha}$ under gamhar and $823 \mathrm{Kg} / \mathrm{ha}$ under mangium. Similarly mangoginger exhibited maximum rhizome yield of $3300 \mathrm{Kg} / \mathrm{ha}$ under open condition followed by $1979 \mathrm{Kg} / \mathrm{ha}$ under gamhar and $1597 \mathrm{Kg} / \mathrm{ha}$ under mangium. Kalmegh and mangoginger yield less under trees than open condition may be because of availability of less light under trees. Reduction of yield of different crops under trees has also been reported by various researchers in cowpea raised under coconut (George and Nair, 1987), three wheat varieties grown under Populus deltoides (Singh et al., 1993), Cicer arietinum, Brassica juncea and Dolichos lablab intercropped with $C$. equisetifolia, Adina cordifolia and Gmelina arborea (Maheta et al., 1996), Prosopis cineraria with Cassia angustifolia (Vyas, 2001), D. sissoo with sesamum (Naugraiya and Jhapatsingh, 2005) and C. equisetifolia, E. hybrid, D. sissoo and Tectona grandis with ragi, sesamum, black gram and cowpea (Mohanty et al., 2008). The trend of 
Table 3. Solar radiation interception under canopy of intercrops (\% of open field) under agrisilvicultural system (X100, LUX $2,00,000)$.

\begin{tabular}{lccc}
\hline Treatment & September, 2011 & October, 2011 & November, 2011 \\
\hline $\mathrm{T}_{1}$-Mangium + Pineapple & 15.6 & 13.1 & 10.4 \\
$\mathrm{~T}_{2}$ - Mangium + Aloevera & 15.3 & 12.2 & 8.2 \\
$\mathrm{~T}_{3}$ - Mangium + Kalmegh & 22.2 & 18.9 & 15.0 \\
$\mathrm{~T}_{4}$ - Mangium + Mangoginger & 12.7 & 19.4 & 17.8 \\
$\mathrm{~T}_{5}$ - Gamhar + Pineapple & 19.0 & 16.1 & 14.6 \\
$\mathrm{~T}_{6}$ - Gamhar + Aloevera & 27.8 & 24.6 & 21.0 \\
$\mathrm{~T}_{7}$ - Gamhar + Kalmegh & 26.2 & 28.0 & 32.7 \\
$\mathrm{~T}_{8}$ - Gamhar + Mangoginger & 15.9 & 30.8 & 26.5 \\
$\mathrm{~T}_{9}$ - Pineapple & 20.8 & 17.5 & 15.4 \\
$\mathrm{~T}_{10}$ - Aloevera & 30.3 & 28.3 & 25.7 \\
$\mathrm{~T}_{11}$ - Kalmegh & 32.7 & 37.3 & 47.2 \\
$\mathrm{~T}_{12}$ - Mangoginger & 30.8 & 38.6 & 34.7 \\
$\mathrm{SEm}_{( \pm)}$ & 1.21 & 1.49 & 2.09 \\
$\mathrm{CD}_{(0.05)}$ & 3.56 & 4.37 & 6.12 \\
\hline
\end{tabular}

Table 4. Economics of the different tree-crop combinations (Rs/ha) under agrisilvicultural system.

\begin{tabular}{lcccc}
\hline Treatment & Gross return (Rs.) & Net return (Rs.) & Net return (US \$) & BCR \\
\hline $\mathrm{T}_{1}$ - Mangium + Pineapple & 441334 & 253004 & 4213 & 2.34 \\
$\mathrm{~T}_{2}$ - Mangium + Aloevera & 374199 & 176127 & 2933 & 2.10 \\
$\mathrm{~T}_{3}$ - Mangium + Kalmegh & 330769 & 180769 & 3010 & 2.20 \\
$\mathrm{~T}_{4}$ - Mangium + Mangoginger & 298968 & 148968 & 2481 & 1.99 \\
$\mathrm{~T}_{5}$ - Gamhar + Pineapple & 243012 & 103341 & 1721 & 1.65 \\
$\mathrm{~T}_{6}$ - Gamhar + Aloevera & 195825 & 50825 & 846 & 1.30 \\
$\mathrm{~T}_{7}$ - Gamhar + Kalmegh & 188009 & 68009 & 1133 & 1.56 \\
$\mathrm{~T}_{8}$ - Gamhar + Mangoginger & 165521 & 45521 & 758 & 1.37 \\
$\mathrm{~T}_{9}$ - Pineapple & 108280 & 39950 & 665 & 1.58 \\
$\mathrm{~T}_{10}$-Aloevera & 63855 & 8855 & 147 & 1.16 \\
$\mathrm{~T}_{11}$-Kalmegh & 68145 & 34145 & 569 & 2.27 \\
$\mathrm{~T}_{12}$-Mangoginger & 66000 & 36000 & 600 & 2.19 \\
$\mathrm{SEm}_{( \pm)}$ & 9586 & 5132 & 85 & 0.07 \\
$\mathrm{CD}_{(0.05)}$ & 28113 & 15049 & 251 & 0.19 \\
\hline
\end{tabular}

crop yield both under trees and open condition was: pineapple $>$ aloevera $>$ mangoginger $>$ kalmegh. The economic evaluation in terms of gross return, net return and Benefit Cost Ratio (BCR) varied significantly under different tree-crop combinations (Table 4). The gross return of different tree-crop combinations ranged from Rs 63855/ha to Rs. 441334/ ha. Mangium-pineapple combination generated highest gross return as compared to other combination and sole crops. This may be due to combined better performance of mangium and pineapple under agrisilvicultural system. The net return of different treatments varied from Rs. 8855/ha to Rs. 253004/ha. Mangium-pineapple combination was proved to be the best combination among the treatments tried from economic return point of view which may due to best performance of mangium as well as pineapple in agrisilvicultural system of rainfed upland condition. Similarly the BCR of different tree-crop combinations varied from 1.16 to 2.34 . It was found highest in mangium-pineapple combination (2.34) and lowest in aloevera as sole crop (1.16). This may be attributed to proportionately higher gross return in comparison to cost in case of mangium- pineapple, while in case of aloevera it may be due to proportionately less gross return in comparison to cost. Overall the economics of agroforestry system was appreciably higher than sole cropping. The higher return from agroforestry systems in comparison to sole cropping has been reported in coconut based farming system intercropped with rice, millet, grain legumes, oilseed crops, root crops, banana, pineapple and chillies (Das, 1991), sunflower, pigeon pea and pearl millet raised in Leucaena leucocephala and E. hybrid (Ramshe et al., 1994), coconut with ginger, turmeric and colocasia (Sharma et al., 1996), sorghum, groundnut and grass grown under teak and subabul (Mutanal et al., 2006), arable crops like maize, paddy fodder maize and sunhemp raised in horticultural crop sapota and silvicultural crops like $E$. tereticornis, Albizia molucana, C. equisetifolia, T. grandis and Dalbergia sissoo (Patil et al., 2010), poplar ( $P$. deltoides) based agroforestry system (Jain and Singh, 2000), pearl millets and toria (Brassica tournefortii) in Khejri (Kaushik and Kumar, 2003) and coconut and guava based multistoried agroforestry system with medicinal crop like Aloe indica, Asparagus racemosus and Kaempferia angustifolia (Bari and Rahim, 2012). 


\section{Conclusion}

A. mangium (mangium) performed better in terms of growth and yield than G. arborea (gamhar) at 11 years of age and pineapple proved its superiority over other intercrops in terms of yield and return with mangium in combination. Therefore, A. mangium and pineapple based agrisilvicultural system may be preferred for rainfed uplands of Odisha.

\section{REFERENCES}

Acciaresi, H., Ansiu, O.E. and Marlats, R.M. (1994). Silvopastural systems: effects of tree density on light penetration and forage production in poplar (Populus deltoides). Agroforestry-en-la-Americas, 1(4): 6-9.

Bari, M.S. and Rahim, M.A. (2012). Economic evaluation and yield performance of some medicinal plants in coconut based multistoried agroforestry systems. The Agriculturists, 10 (1): 71-80.

Batish, D.R., Kohli, R.K., Jose, S. and Singh, H.P (2007). Ecological Basis of Agroforestry. CRC Press, New York.

Batra, L. and Kumar, A. (1994). Biomass production and nitrogen accumulation of Rhodes grass and three tree species in an agroforestry system under alkali soil conditions. Agroforestry Systems for Degraded Lands, Oxford and IBH Publishing Co. Pvt. Ltd., New Delhi, pp. 713-719.

Chaturvedi, O.P. and Krishnan, P.R. (2009). Ecosysystem development through agroforestry measures. Agroforestry; Natural Resources Sustainability, Livelihood and Climate Moderation. Satish Serial Publishing House, Delhi, pp. 55- 70.

Couto, L. and Gomes, J.M. (1995). Intercropping Eucalyptus with beans in Minas Gerais, Brazil. International Tree Crop Journal, 8(213): 83-93.

Das, P.K. (1991). Economic viability of coconut based farming system in India. Journal of Plantation Crops, 19(2): 191-201.

Dhyani, S.K. and Chauhan, D.S. (1989). Evaluation of crops in relation to shade intensities of Khasipine (Pinus khasya): Progress Report. ICAR Research Complex, Shillong.

Dogra, A.S. (2007). Contribution of trees outside forests toward wood production and environmental amelioration. Indian Journal of Ecology, 38: 1-5.

George, S. and Nair, V. R. (1987). Effect of shade on growth, nodulation and yield of cowpea (Vigna unguiculate L. Walp). Agriculture Research Journal Kerala, 25(2): 281-284.

Jain, S.K. and Singh, P. (2000). Economic analysis of industrial agroforestry: poplar (Populus deltoides) in Uttar Pradesh (India). Agroforestry Systems, 49: 255-273.

Jasural, S.C., Mishra, V.K. and Sharma, S.K. (1993). Intercropping of ginger and turmeric with poplar (Populus deltoides 'G-3' Marsh). Agroforestry Systems, 22(2): 111-117.
Jaychandran, B.K., Meerabai, M., Abdulsalam, M., Mammen, M.K. and Kunjammap, M. (1991). Performance of ginger under shade and open conditions. Indian Cocoa, Areca nut and Spices Journal, 15(2): 40-41.

Kaushik, N. and Kumar, V. (2003). Khejri (Prosopis cineraria)-based agroforestry system for arid Haryana, India. Journal of Arid Environments, 55: 433-440.

Korwar, G.R., Pratibha, G., Ravi, V. and Kumar, D. P. (2006). Performance of castor (Ricinus communis) and greengram (Vigna radiata) in agroforestry systems in semi arid tropics. Indian Journal of Agronomy, 51(2): 112-115.

Maheta, K.B., Kukadia, M.U., Vashi, B.G. and Jadeja, D.B. (1996). Effect of forest tree species on the yield potential of intercrops. Indian Forester, 122(7): 651-653.

Miah, M.G., Argon, M.L. and Garrity, D.P. (1997). Growth, biomass production and distribution of three multipurpose tree species in an agroforestry system as affected by pruning. Journal of Tropical Forest Science, 10:35-49.

Mohanty, S., Mohanty, A. K., Mishra, D. and Gantayat, B. P. (2008). Effect of association of tree species on grain production of intercrops: Annual Report. AICRP on Agroforestry, Bhubaneswar.

Mutanal, S. M., Prabhakar, A. S., Nadagoudar, B. S. and Mannikeri, I. M. (2006). Effect of Teak on yield and yield components of field crops. Indian Forester, 132 (8): 980-985.

Naugraiya, M. N. and Jhapatsingh, P. (2005). Performance of Dalbergia sissoo and Sesamum indicum under rainfed agrisilviculture system in eintisols. Journal of Tropical Forestry, 21: 20-22.

Pandey, D.N. (2007). Multifunctional agroforestry in India. Current Science, 92(4): 455-463.

Patil, S. J., Mutanal, S.M., Patil, H.Y., Shahapurmath, G. and Maheswarappa, V. (2010). Performance of sapota- Teak based agroforestry system in hill zone of Karnataka. Indian Journal of Agroforestry, 12 (1):27-34.

Puri, S., Rao, B. and Swamy, S.L. (2001). Growth and productivity of wheat varieties in an agrisilviculture system. Indian Journal of Agroforestry, 3(2): 134-138.

Ramshe, D.G., Umarani, N.K., Khade, K.K., Walunjkar, R.B. and Tambe, T.B. (1994). Effect of association of tree species on grain production of arable rainy season crops. Indian Journal of Agronomy, 39(2): 188-192.

Sharma, R., Prasad, S., Mohan, N.K. and Medhi, G. (1996). Economic feasibility of growing some root and tuber crops under intercropping system in coconut garden. Horticulture Journal, 9(2): 167-170.

Singh, A., Dhanda, R. S. and Ralhan, P. K. (1993). Performance of wheat varieties under poplar (Populus deltoids Bartr.) plantation in Punjab (India). Agroforestry Systems, 22(1): 83-86.

Vyas, S.P. (2001). Effect of Prosopis cineraria on growth and productivity of Cassia angustifolia under Medico forestry system in arid region of Thar Desert. Journal of Tropical Forestry, 17(3): 71-73. 